\title{
Aumento Dos Biomarcadores Inflamatórios, Apoptóticos e do Dano Ao DNA Em Pacientes Após Acidente Vascular Encefálico.
}

\author{
Righi, F.L.; Bertazzo, T.L.; Pascotini, E.T.; Fighera, M.R.; Cardoso, A.S.; \\ Haupenthal, F.; Flores, A.E.; \\ Apresentador: Taíse Leitemperger Bertazzo
}

\section{Resumo}

Introdução: O Acidente Vascular Encefálico

(AVE) é uma das principais causas de morte e incapacidade associado a sequelas relacionadas com o dano cerebral. Entre os mecanismos etiológicos associados estão a excitoxicidade, a sinalização apoptótica e processos inflamatórios. Essa cascata de eventos pode ativar astrócitos e células microgliais que, consequentemente, liberam mediadores inflamatórios, como a interleucina 1? (IL-1 ?) e Fator de Necrose Tumoral alpha (TNF-?). Esses marcadores inflamatórios podem ativar seus receptores associados a domínio de morte, e causar a ativação das caspases 1 e 3 , que conduzem a uma disfunção celular. Assim, esse estudo objetiva investigar a associação entre marcadores inflamatórios, apoptóticos e de dano ao DNA nos pacientes após AVE em humanos. Médodos: Pesquisa realizada com pacientes do ambulatório de fisioterapia e de neurologia do Hospital Universitário (HUSM) da UFSM. Foi coletada uma amostra de sangue para determinação dos níveis de IL-1 ?, TNF-?, caspase 1 e 3 e indicador de dano ao DNA pela técnica de picogreen. Resultados: Característica dos pacientes do grupo intervenção: A pesquisa foi realizada com 40 pacientes, sendo 27 (67,5\%) do sexo masculino, com idade média de 60,5 anos. Em relação ao hemisfério afetado, $13(32,5 \%)$ pacientes sofreram AVE no hemisfério esquerdo e 27 no hemisfério direito (67,5\%). Houve aumento dos níveis séricos de TNF? $(\mathrm{t}=14.23 \mathrm{pg} / \mathrm{ml}), \mathrm{IL}-1(\mathrm{t}=18.39 \mathrm{pg} / \mathrm{ml})$, Caspase 3 $(\mathrm{t}=6.821 \mathrm{Fl} / \mathrm{min} / \mathrm{ml})$, Caspase $1(\mathrm{t}=6,985 \mathrm{Fl} / \mathrm{min} / \mathrm{ml})$ e dano ao DNA $(\mathrm{t}=7.777 \mathrm{pg} / \mathrm{ml})$ no grupo com AVE em comparado ao grupo controle. Foi considerado significativo $\mathrm{p}<0,05$. Conclusão: Os resultados encontrados sugerem que o dano cerebral observado no AVE pode estar associado com a ativação das vias inflamatórias e apoptóticas, representado pelo aumento da IL-1?, TNF-?, caspases 1 e 3 no sangue de pacientes com AVE em comparação com grupo controle saudável e o consequente dano ao DNA.

\section{Referência:}

Righi, F.L.; Bertazzo, T.L.; Pascotini, E.T.; Fighera, M.R.; Cardoso, A.S.; Haupenthal, F.; Flores, A.E.; Aumento Dos Biomarcadores Inflamatórios, Apoptóticos e do Dano Ao DNA Em Pacientes Após Acidente Vascular Encefálico.. In: II Congresso Brasileiro de Medicina Hospitalar - II CBMH [= Blucher Medical Proceedings, vol.1, num.5] São Paulo: Editora Blucher, 2014. p.81

DOI 10.5151/medpro-Il-cbmh-079 